\title{
The Investigation of Social Communication Apprehension and Motives for Social Network Sites Usage
}

\author{
Serra İnci Çelebi'
}

\begin{abstract}
The main purpose of this study is to investigate the possible connection between social network sites (SNSs) usage and communication apprehensiveness or communication easiness. Survey was conducted $(\mathrm{N}=229)$ to find a possible connection between communication apprehension or easiness and the use of SNSs in addition to the motives for the use of some popular SNSs. The survey was conducted at a private university in Turkey and probability sampling was used to select the sample from the population. It was found that socially communicative individuals connected to SNSs for long hours. Facebook users were drawn by two leading motives to use Facebook: relaxing entertainment and professional advancement. Expressive information sharing was the main reason why users connected to Twitter. The motives for using Google+ were meeting with new people, and habitual pass time-companionship. Escapism and habitual pass time-companionship motivate individuals to use SNSs more frequently and for long hours. On the other hand, individuals who have a need for 'meeting new people' had more number of SNSs. The findings were discussed by using several theoretical perspectives (e.g., the rich get richer, and $U \& G$ ) in the results section and included practical recommendations and further suggestions.
\end{abstract}

Keywords: Communication apprehension, social network sites (SNSs), motives, uses and gratifications (U\&G), and social media behaviours.

\section{Sosyal İletișim Endișesi ve Sosyal Ağları Kullanma Motivasyonlarının Incelenmesi}

\begin{abstract}
Öz
Bu çalışmanın temel amacı sosyal ağ kullanımı ile iletişim kaygısı veya iletişim kolaylığı arasında mümkün olabilecek bir bağlantıyı araştırmaktır. Popüler olan bazı sosyal ağların yanısıra sosyal ağları kullanma kolaylığı ile iletişim kaygısı arasında var olabilecek bir bağlantıyı bulabilmek için anket uygulanmıştır $(\mathrm{N}=229)$. Anket çalışması Türkiye'de özel bir üniversitede yapılmış ve olasılıklı örnekleme yöntemi kullanılarak örneklem oluşturulmuştur. Sosyal açıdan konuşkan bireylerin sosyal ağlara daha uzun süreyle bağlandıkları bulunmuştur. Eğlendirirken dinlendiren ve mesleki gelişim olmak üzere iki tane önde gelen motivasyon Facebook kullanıcılarını Facebook'a yönlendiren nedenlerdir. Anlatımsal bilgi paylaşımı, kullanıcıların Twitter'a bağlanmalarının temel nedenidir. Google+ kullanma motivasyonları ise yeni insanlarla tanışma ve arkadaşılık ederek alışkanlığa bağlı zaman geçirmedir. Bir şeylerden kaçış ve arkadaşlık ederek alışkanlığa bağlı zaman geçirme motivasyonları, kişilerin sosyal ağları daha sık ve daha uzun süre kullanmalarına neden olmaktadır.Öte yandan, yeni insanlarla tanışma intiyacı olan bireyler daha fazla sayıda sosyal ağ üyesi. Sonuçlar kısmında bulgular birkaç teorik perspektif kullanılarak tartışılmış (örneğin: varlıklı daha da varlıklı olur ve kullanımlar ve doyumlar) ve uygulamaya yönelik ve ileriye yönelik öneriler yapılmıştır.
\end{abstract}

Anahtar Kelimeler: İletişim kaygısı, sosyal ağlar, motivasyonlar, kullanımlar ve doyumlar ve sosyal medya davranışları.

1 Doç.Dr., Yaşar Üniversitesilletişim FakültesiHalkla Ilişkiler ve Reklam Bölümü 


\section{Introduction}

A mong SNSs, Facebook has been the most engaging and leading site with its users over 1 billion 400 million ("Leading social", n.d.)and according to one of the latest research, engagement of using Facebook continues to grow (Duggan, Ellison, Lampe, Lenhart, and Madden, 2015). Turkey is the 5th biggest Internet user country among Europe's top 10 Internet countries according to Internet World Stats based on data gathered on 30th of June 2014 ("Internet top", 2014) and has 46,282,850 Internet users ("Internet stats", 2014). "45 per cent of the population in Turkey are active Facebook users, which means 93 per cent of Internet users in Turkey have a Facebook account" (Akdenizli, 2015: xv). According to 2014 data, with 32 million users, Turkey is the $7^{\text {th }}$ Facebook user country in the world (“Top 10", 2014).

Social interaction is a fundamental function of social media, and other media such as television and radio don't offer social interaction, therefore they are not perceived as social (Wang, Tchernev, and Solloway, 2012). Social means "relating to activities that involve being with other people, especially activities that you do for pleasure" (e.g., a social person enjoys being with other people) ("social", n.d.). Social media means that "websites and applications that enable users to create and share content or to participate in social networking" ("social media", n.d.).

Social network sites are defined as "web-based services that allow individuals to (1) construct a public or semi-public profile within a bounded system, (2) articulate a list of other users with whom they share a connection, and (3) view and traverse their list of connections and those made by others within the system" (Boyd and Ellison, 2007: 211).Social network sites (SNSs) provide multiple opportunities for their users and these range from sending e-mails and instant messages, and sharing pictures, photos, videos, and blogs to inviting friends and colleagues to have access to the profiles that have been previously created by the individuals (Kaplan and Haenlein, 2010). "Social networking services offer friends a space where they can maintain their relationships, chat with each other and share information. Moreover, they offer the opportunity to build new relationships through existing friends" (Rohani and Hock, 2010: 42).

There are some comparative studies on the motives of using SNSs (e.g., Kim, Sohn and Choi, 2011) which reveal that although the major motives (such as seeking friends, entertainment) were the same, Americans put emphasis on seeking entertainment while Koreans put weight on keeping in touch and getting support from their social relationships. Some studies aimed at investigating motives for Facebook usage (Baek, Holton, Harp and Yaschur, 2011; Ross, Orr, Sisic, Arseneault, Simmering, \& Orr, 2009; Smock, Ellison, Lampe and Wohn, 2011), the adoption of Facebook among youth (Mustafa, Ibrahim, Mahmud, Ahmad, Kee and Mahbob, 2011), compared Twitter and Facebook use from personality predictors of social media use (Hughes, Rowe, Batey and Lee, 2012), compared MySpace and Facebook (Raacke \& Bonds-Raacke, 2008), and compared Facebook, Twitter, YouTube use according to working memory, attention skills, and social connectedness (Alloway and Alloway, 2012).

This study aims to extend the uses and gratifications (U\&G) theoretical perspective by including social communication apprehension scale in social media (SM) studies. By this theoretical extension, SM use can be better understood in a way to show whether or not there is an effect of communication apprehensiveness of a person on SM use. 


\section{Theoretical Frameworks}

\subsection{Communication Apprehension}

"Communication apprehension is defined as the level of fear or anxiety associated with either real or anticipated (oral) communication encounters" (Woods, 2007: 320; see also Berry, 2007). Communication apprehension is linked to a series of social withdrawal behaviours such as less talk and remote seating and housing (McCroskey and Sheahan, 1978). The people who experience apprehensiveness in communication avoid communicative contact (Berger, Richmond, McCroskey and Baldwin, 1984) and communication due to emotional distress during communication, and those people are perceived as less successful, skilled, and competent (McCroskey, Booth-Butterfield and Payne, 1989). Persons with high communication apprehension are less likely to communicate than persons with low communication apprehension (Watson, 2007). Some individuals are more apprehensive than others and this apprehension effects their daily communication negatively. Furthermore, the degree of communication apprehension varies from one person to another. Extremely apprehensive individuals avoid communication due to the fear or anxiety that they have learned associations about communication. Some others may hold mild apprehensiveness that they may not exhibit fear during their communication (Pitt and Ramaseshan, 1990).

People who have apprehensiveness in their communication may prefer use of a medium in place of face to face communication. One study revealed that some individuals who preferred talking on a radio talk show program didn't prefer face to face communication. The people who talked on radio talk show programs listened to the radio for more hours than people who didn't prefer talking but preferred listening to the radio (Armstrong and Rubin, 1989). In another study, people who had communication apprehension mostly preferred using pagers, cellular phones, and advanced phone capabilities when they were compared with those who had computer anxiety (Scott and Rockwell, 1997). Burke, Marlow, and Lento (2010) found that there was association with the SNS interactions between the user and another friend and the user's lower level of loneliness. When the amount of communication on the SNSs increased, loneliness decreased and the user felt less lonely. McCord, Rodebaugh, and Levinson (2014) found that people with high social anxiety used frequently social feature of Facebook.

Communication apprehension is the most commonly used and researched concept in communication studies (Wrench, Brogan, McCroskey and Jowi, 2008). Although, it is still consistently researched and discussed, its use and research in social media is not wide. The studies generally focused on investigating computer-mediated communication (CMC) apprehension and the use of SNSs (e.g., Ho \& McLeod, 2008; Hunt, Atkin and Krishnan, 2012; Wrench and Punyanunt-Carter, 2007); while leaving a research gap for a possible relationship between social communication apprehension and the use of SNSs.

As Campbell (2006: 87) indicated "User apprehension is one factor generally overlooked when assessing the effectiveness of new communication technologies"; and obviously social communication apprehension can either reduce or increase an individual's effectiveness and duration of using SNSs. Zhang, Tang, and Leung, (2011) examined the connection between traitlike communication apprehension and Facebook usage. They found that anxiety in communication negatively affected Facebook engagement.

Communication apprehension is divided into two groups: trait and state apprehension. In the 
current study, communication apprehension is being measured within the context of social communication apprehension. Trait-like communication apprehension is different than social communication apprehension and it can be clarified as "a relatively enduring, personality-type orientation toward a given mode of communication across a wide variety of context" (McCroskey, 1984: 16). Trait-like communication apprehension is a personality variable, which can be changed in adulthood, although it is highly resistant to change. In addition to the trait-like nature of a person, a person may be apprehensive in a particular setting or a specific condition such as family get-to-gathers, friends meetings and parties. Social communication apprehension can be defined as "individual's level of fear or anxiety associated with either real or anticipated communicative interaction with another person or persons during a social gathering" (Wrench, Brogan, McCroskey and Jowi, 2008: 411).

\subsection{The Rich Gets Richer vs. the Poor Gets Richer Hypothesis}

There are two competing hypotheses: the rich get richer hypothesis and the poor gets richer hypothesis. The rich get richer effect, which is also called as the social enhancement (or the Matthew effect), states that people who are good at offline social settings are also the ones who are good at online social environments. According to the poor gets richer hypothesis, which is also called the social compensation, people who do not have sufficient offline social surroundings, have extensive online social networks (Zywica and Danowski, 2008; See also Tufekci, 2010).

Tufekci (2010) studied social media and found that personal characters and some personality traits affect some people to build online relationships and others to create offline relationships. There are increasing numbers of SNS users all around the world, and this abundance in number increases researchers' curiosity for finding an answer to define the characters of people who may tend to rely upon SNSs in their social relationships and interactions with others (Correa, Hinsley and de Zúñiga, 2010). Some of the previous research investigated how the personality traits of the Big-Five affect SNS use. Correa, Hinsley, and de Zúñiga, (2010) for example, found two important personality traits, which were extraversion and openness to experience positively, related to social media use. Hughes, Rowe, Batey and Lee (2012) compared Twitter and Facebook and found that Facebook users were extraversion, neuroticism and higher in sociability; while Twitter users showed conscientiousness, openness and sociability. Gosling, Augustine, Vazire, Holtzman, and Gaddis (2011) researched a relationship between the Big Five personality traits and Facebook use and found that extraversion predicted frequency of Facebook usage and engagement in Facebook site. Ross, Orr, Sisic, Arseneault, Simmering, and Orr (2009) examined how the BigFive effects Facebook use and found that personality factors were not as influential as they were previously found and literally written.

When people fail in interpersonal communication, they may turn to mass media which is considered as an alternative to their loneliness. So, it is stated that lonely people more often use the mass media over interpersonal communication (Wang, Fink and Cai, 2008). Erdoğan (2008) in his study found that increased Internet usage and Internet attitudes were related to Turkish adolescents' loneliness. On the other hand, Sheldon (2008) examined the relationship between unwillingness to communicate in interpersonal communication and Facebook use; she found people who were willing to communicate in social settings were also the ones who were active in online relationships. Miyata and Kobayashi (2008) found in their studies that people's abundance of social ties increases their use of personal computers and mobile phones for e-mailing them. This result is important from a social networking perspective. 
Does an individual's social communication apprehension or easiness encourage or discourage the use of SNSs? Is there any difference on experience and frequency of use, hours spent on, or the number of owing SNSs between socially communicative and socially comprehensive people? One thing is obvious that either in a negative or in a positive way there must be a correlation between SNS usage and social communication easiness or apprehension. Thus, based on the abovementioned discussion, the first research question is formulated as below:

RQ1: Do socially communicative or apprehensive individuals use SNSs for long hours?

\subsection{The Uses and Gratifications Theory and the Motives Offered by SNSs}

The Uses and Gratifications theory (U\&G) clarifies that audiences choose some media channels and some contents due to satisfying some social and psychological needs. To do this, audiences assess the benefits of using certain media (Lee \& Ma, 2012). According to the U\&G, persons are active communicators, aware of their needs, can assess communication channels and select to gratify their needs (Perse and Courtright, 1993).

"They emphasize that U\&G studies have two distinct approaches: how needs are gratified by media and how gratifications reconstruct needs" (Smock, Ellison, Lampe, \& Wohn, 2011: 2323). Gratification is defined in Oxford dictionary as "pleasure, especially when gained from the satisfaction of a desire" ("Gratification", n.d.). Watching television, reading, listening to the radio, or spending time with family and friend members may be preferred to kill time or to relax (Katz, Blumer and Gurevitch, 1973).

Early media effects studies historically focused on 'what media can do to passive audiences', but the U\&G studies didn't see the audiences as passive audiences but active media users who act upon their needs instead (Wang, Tchernev and Solloway, 2012)."The meteoric growth of the Internet has produced a renaissance in the uses and gratifications tradition as scholars are increasingly interested in going beyond discovering who uses the Internet to examine why they use this new medium" (Kaye and Johnson, 2004: 197).

According to some research results, gratifications (e.g., entertainment, information sharing, companionship, and social interaction) that are gathered by using social media are important (Lee and Ma, 2012; Smock, Ellison, Lampe, Wohn, 2011). Papacharissi and Rubin (2000) identified five motives for Internet use (Interpersonal utility, passing time, information seeking, convenience, and entertainment); Smock, Ellison, Lampe, and Wohn (2011) categorized nine motives for SNS use (relaxing entertainment, expressive information sharing, escapism, cool and new trend, companionship, professional advancement, social interaction, habitual pass time, and to meet new people); finally, Kaye and Johnson (2002) defined four motives for getting online political information (guidance information-seeking, surveillance, entertainment, and social utility).

Generally the Internet, more specifically social networking sites (SNSs), along with the traditional media offers users more media and content choices (Lee and Ma, 2012). Social needs are considered as the most impacted drivers that stimulate individuals to connect to SNSs for starting, maintaining, and enhancing social relationships (Wang, Tchernev and Solloway, 2012).

Getting social support, reducing uncertainty on particular subjects, forming and maintaining relationships, and so on are some of those needs (motives) that users connect to SNSs 
(Stefanone, Hurley and Yang, 2013). One of those needs is called escapism, which refers to persons' usage of SNSs to get rid of boredom and stress. For these people, SNSs gratify their needs to escape from daily stressful routines and provide pleasurable and enjoyable activity (Zhou and Bao, 2002). Zhang, Tang, and Leung, (2011) examined motives for Facebook and found that Facebook users gratify for social surveillance, recognition, entertainment, and network maintenance needs. Zhang et al. also found that Facebook users were addictive users and very reliant on their networking sites.

What makes Facebook so powerful today is no one seemed to be on Google+ or on new SNSs, so it is obviously the dominant social network. However, by creating new and more motivate social networks you can engage people as in the case of Twitter. Twitter attracted huge audiences by offering options and services different than Facebook's offers (Clark, 2013).We can see, for example, Twitter use increases all around the world especially during natural disasters (e.g., earthquake in Turkey or tornado in the U.S.) (Maxwell, 2012). The main motivations of Twitter use are interpersonal utility and passing time which are also motives of other SNS usage (Holton, Baek, Coddington and Yaschur, 2013).

It seems that although many people share the same networking platform, Facebook has started to lose its popularity, as Google+ started to take share from the competition pie (Dachis, 2013). While Google+ has been slowly but surely winning ground, Facebook users turns into passive, as they post less but read more on Facebook (“Longitudinal study", 2014).

Miller (2014) claims that Google+ is not a ghost town anymore despite what other people write or say. She adds that Google+ has combined many features and therefore a unique social networking platform so far invented. By connecting to Google+, you can meet and interact with your potential customers and people of interest, which you cannot do with Facebook. Because, Google+, rather than Facebook, is suitable for long conversations which build relationships (Clark, 2013).

Researchers found that spending more time on Facebook depends on how much the users were entertained and passed their time away by using it. Both entertainment and passing time were the main motivational factors for devoting more time on Facebook (Hunt, Atkin, and Krishnan, 2012; Hess, 2012).

Nadkarni and Hofmann (2012) suggest that Facebook users are motivated by two drivers, namely the need to belong and the need for self-presentation. Because of the different natures of SNSs, their motives should be different too. In order to learn more about social media users' uses and gratifications, the following research questions are asked:

RQ2: What gratifications do users obtain from SNS use? and Which type of SNS usage motives affects users' usage patterns (e.g., frequency, long hours, the number of SNSs?

RQ3: Does the choice of SNS change according to different type of motivation?

\section{Methodology}

\subsection{Sampling}

When we look at the characteristics of SNS users, we can see that majority of youngsters 
actively use them. Therefore, this study was conducted on university students. The survey was implemented at a private university in the Western part of Turkey. A pool of UFND (university foundation) courses and classes were listed; then all the clusters randomly picked by giving them equal chances to be selected. Out of a total number of fifty seven UFND classes, seventeen UFND classes were produced randomly. UFND courses are compulsory courses that students should be registered in, in order to graduate from the university. The name of UFND courses can be found in the appendix A. Cluster sampling was employed and the sample size is 229. Since random sampling was used, the sample of this study is a representative of the students at the university; however, sample size of 229 is small to generalize the sample to the population in Turkey.

The respondents were between the ages of 18 and $22+$ years old. Females (53.7\%) were slightly more than males $(46.3 \%)$. The students were the representative of all departments (seven faculties and one vocational high school) of the university; however, the majority of participants were from the faculty of economics and administrative science $(23.2 \%)$ and less participation was from faculty of art and design (1.8\%). Freshmen (50.7\%) were slightly more than half of the entire respondents.

Table 1. Demographic Profile of Respondents

\begin{tabular}{lrr}
\hline & Frequency & $\%$ \\
\hline Gender & 106 & 46.3 \\
Male & 123 & 53.7 \\
Female & \\
$\quad$ Department & & \\
Faculty of Communication23 & 10.0 & \\
Faculty of Engineering & 50 & 21.9 \\
Faculty of Science \& Letters & 15 & 6.7 \\
Faculty of Law & 33 & 14.5 \\
Faculty of Architecture & 16 & 7.0 \\
Faculty of Econ. \& Admin. Sci. & 53 & 23.2 \\
Faculty of Art \& Design & 4 & 1.8 \\
Higher School of Vocati. Leaming 34 & 14.9 \\
$\quad$ Year in University & 116 & 50.7 \\
Freshman & 71 & 31.0 \\
Sophomore & 34 & 14.8 \\
Junior & 7 & 3.1 \\
Senior & 1 & 0.4 \\
Other & \\
\hline
\end{tabular}

Note: $\mathrm{N}=229$.

In this study instead of communication apprehension, social communication apprehension was assessed for understanding the usage of the SNSs and the Social Communication Apprehension Scale developed by Wrench, Brogan, McCroskey, and Jowi in 2008 has been used for this purpose. The original scale had 18 items, but 16 of them were included in this study and some items (e.g., bar) were modified so that they would be culturally more acceptable. Although there are night clubs and pubs in Izmir, it is hardly to say that the majority of students visit them on a regular basis. Both male and female students, on the other hand, visit some places such as restaurants (sometimes can be seen as cafe-restaurant), cafeterias (sometimes can be seen as cafe-pub) and parks in Izmir. The items used in this study and in Wrench et al.'s study can be found in the appendix B. 
Motives for SNSs use were assessed employing scales which are used in a study by Smock, Ellison, Lampe, and Wohn (2011). However, Smock et al's (2011) scale included only one item in the "to meet new people" section; their scale was extended by allowing four more items to this section and those items can be viewed in the appendix $\mathrm{D}$.

A 5-point Likert-scale ranging from "Strongly Disagree" to "Strongly Agree" is used to measure attitudes and behaviours toward both motives for social media use and social communication apprehension. Close-ended questions were used to gather demographic information and information on SNS usage.

\subsection{Dependent and Independent Variables}

The seven motives and social communication apprehension were used as independent variables of this study. The number of SNSs, the years of using SNSs, the frequency of using SNSs, and the hours of using SNSs were used as dependent variables.

\subsection{Statistics}

The latest version of SPSS 22.0 (Statistical Package for Social Sciences) was used to analyse the findings of this study. Frequency, regression analysis and factor analysis were conducted for this study.

\subsection{Validity}

The validity of both the motives of using SNSs and social communication apprehension were assessed by maximum likelihood in factor analysis. Out of 9 motives 7 of them were valid. There is no validity for 'cool and new trend' motivation and two motives were merged and became 'habitual pass time-companionship'. 2 factors (communication anxiety and communication easiness) found for social communication apprehension and 7 factors (habitual pass time and companionship, relaxing entertainment, professional advancement, to meet new people, expressive information sharing, escapism, social interaction) for the motives of using SNSs were found.

\subsubsection{Factor Analysis Results for Social Communication Apprehension}

Factor analysis was conducted to find the structure of the scale and maximum likelihood was used as an extraction method. The results revealed two factors and they found 8 items had their higher loading on Factor 1 and the other 8 items had their higher loading on Factor 2. So, the scale is essentially unidimensional. Higher scores on Factor 1 are coded to represent anxiety in communication and higher scores on Factor 2 are coded to represent easiness in communication on the scale.

For examining the factorability of the 16 Social Communication Apprehension Scale items three criteria were used. The Kaiser-Meyer-Olkin measure of sampling adequacy was .86, Bartlett's test of sphericity was significant $\left(X^{2}(120)=1547.805, p=.000\right)$, and goodness-of-fit $\left(X^{2}(75)=168.246\right.$, $\mathrm{p}=.000)$.

Eigen values showed that the first two factors explained a total of $37.9 \%$ and $13 \%$ of the variance respectively. The factors were examined by using oblimin rotations of the factor loading matrix and maximum likelihood factor analysis. The two factor solution was preferred because of the 'levelling off' of Eigen values on the screen plot after two factors and the other factors had Eigenvalues below one. 


\section{Table 2. Social Communication Apprehension Scale Factor Analysis}

\begin{tabular}{|c|c|c|}
\hline Items & Factor 1 & Factor 2 \\
\hline 1. I always feel anxious in social situations & .666 & .077 \\
\hline 2. I experience anxiety when I communicate with people in social settings & .733 & .033 \\
\hline 3. Even small get-togethers make me apprehensive & .784 & .009 \\
\hline 4. At a party, I tend to hangout near a wall away from people & .647 & .070 \\
\hline 5. Social interaction makes me anxious & .791 & .056 \\
\hline 6. I get really nervous when I have to interact with people at a party & .659 & .033 \\
\hline 7. I tend to be very apprehensive while communicating in social situations & .580 & .177 \\
\hline 8. I am usually anxious when talking to people in public places & .616 & .076 \\
\hline 9. I am outgoing when surrounded by a lot of people & .002 & .584 \\
\hline 10. I am usually very outgoing at a dinner party & .198 & .441 \\
\hline 11. I am at ease at parties & .102 & .533 \\
\hline 12. Social interaction is the best part of my day & .044 & .355 \\
\hline 13. I am less shy than most people in social situations & .044 & .590 \\
\hline 14. I seldom feel anxious in social situations & .043 & .268 \\
\hline 15. I am usually at ease when talking to people in public places & .018 & .701 \\
\hline 16. I can communicate with people in social settings without experiencing anxiety & .111 & .795 \\
\hline
\end{tabular}

Note: Bold indicates a significant factor loading identifying the item and factor associated with it. $\mathrm{N}=229$. All items shared a common prompt: "Indicate how much you agree with each option by marking the appropriate response" and were measured with a 5-point Likert-scale ranging from "Strongly Disagree" to "Strongly Agree".

For conducting factor analysis maximum likelihood was used as an extraction method. As a result, seven factors were found instead of nine factors. There wasn't factor loading for the motivation of "cool and new trend" and two separate motives were merged, namely 'habitual pass time' and 'companionship'. The results can be seen in Table 5 and the names of each factor can be viewed in appendix $\mathrm{C}$. The motivation of 'To meet new people' was extended by including two more items and they can be seen in the appendix D.

Three well-recognized criteria for the factorability of a correlation were used. Firstly, the KaiserMeyer-Olkin measure of sampling adequacy was .83, above the commonly recommended value of .6, Bartlett's test of sphericity was significant $\left(X^{2}(351)=3233.902, p=.000\right)$, and goodness-of-fit $\left(X^{2}(164)=296.089, p=.000\right)$.

Initial Eigen values indicated that the first seven factors explained $27.8 \%, 14.4 \%, 7.8 \%, 7 \%$, $5.1 \%, 4.6 \%$, and $4 \%$ of the variance respectively. The other factors had Eigenvalues below one and therefore they were not included in this study.

Maximum likelihood factor analysis was conducted to find the structure of the motivation scale and the factors were examined using oblimin rotations of the factor loading matrix. The seven factor solution, which explained $70.7 \%$ of the variance, was preferred because: (1) there was 
the 'flattening out' of Eigen values on the screen plot after seven factors, and (2) the insufficient number of primary loadings appeared and caused difficulty of interpreting the eight factor and subsequent factors.

Table, 3, Social Communication Motivation Scale Factor Analysis

\begin{tabular}{|c|c|c|c|c|c|c|c|}
\hline \multirow[b]{2}{*}{ Items } & \multirow[b]{2}{*}{1} & \multirow[b]{2}{*}{2} & \multicolumn{3}{|c|}{ Factor } & \multirow[b]{2}{*}{6} & \multirow[b]{2}{*}{7} \\
\hline & & & 3 & 4 & 5 & & \\
\hline 1. It is a habit & .670 & .072 & .007 & .012 & .024 & .068 & .025 \\
\hline 2. Have nothing better to do & .649 & .083 & .022 & .031 & .159 & .136 & .096 \\
\hline 3. Occupying my time & .643 & .033 & .197 & .149 & .057 & .158 & .263 \\
\hline 4. It pasas the time away & .529 & .127 & .147 & .059 & .068 & .099 & .155 \\
\hline 5. No one else to talk or be with & .506 & .243 & .025 & .053 & .217 & .191 & .124 \\
\hline 6. Like to play around on SNSs & .492 & .236 & .050 & .107 & .098 & .149 & .075 \\
\hline 7. I won't have to be alone & .451 & .015 & .095 & .084 & .233 & .151 & .182 \\
\hline 8. It makes me feel less lonely & .406 & .166 & .136 & .031 & .244 & .269 & .096 \\
\hline 9. It is enjoyable & .044 & .904 & .073 & .062 & .005 & .078 & .006 \\
\hline 10. It is entertaining & .064 & .850 & .011 & .074 & .017 & 019 & .064 \\
\hline 11. It is relaxing & .034 & .640 & .032 & .009 & .194 & .145 & .046 \\
\hline 12. Helping me network with professional contacts & .084 & .043 & .805 & .024 & .002 & .011 & .097 \\
\hline 13. Posting my resume or other works online & .038 & .008 & .798 & .058 & .014 & .020 & .032 \\
\hline 14. Helpful for my professional future & .120 & .160 & .668 & .022 & .007 & .109 & .056 \\
\hline 15. Chatting with new people & .036 & .059 & .168 & .884 & .028 & .033 & .016 \\
\hline 16. Meeting new people & .007 & .019 & .109 & .828 & .124 & .053 & .066 \\
\hline 17. Exchanging ideas with new people & .016 & .038 & .163 & .731 & .076 & .048 & .015 \\
\hline 18. Providing information on special interest & .110 & .161 & .002 & .017 & .559 & .020 & .076 \\
\hline 19. Sharing information that may be of use & .067 & .046 & .057 & .048 & .427 & .096 & .289 \\
\hline 20. Providing personal information & .041 & .034 & .027 & .089 & .815 & .030 & .026 \\
\hline 21. Telling others about myself & .195 & .054 & .046 & .082 & .672 & .024 & .029 \\
\hline 22. Getting away from what I am doing & .006 & .034 & .081 & .040 & .108 & .876 & .007 \\
\hline 23. Getting away from my family/others & .000 & .048 & .025 & .065 & .035 & .743 & .100 \\
\hline 24. Forgetting about achool, work, others & .100 & .144 & .108 & .038 & .089 & .483 & .013 \\
\hline 25. Communicating with distanced friends & .035 & .124 & .079 & .098 & .025 & .145 & .699 \\
\hline 26. Kesping in touch with friends/family & .177 & .047 & .194 & .007 & .109 & .074 & .514 \\
\hline
\end{tabular}

Note: Bold indicates a significant factor loading identifying the item and factor as sociated with it $\mathrm{N}=229$. All items shased a common prompt: "Indicate how much you agree with exch option by marking the appropriate rasponse" and were masured with a 5-point Likertscale ranging from "Strongly Disagree" to "Strongly A gree". 
There was no factor loading for "cool and new trend" as a result of factor analysis. Factor 1 (habitual pass time \& companionship) included 8 items, factor 2 (relaxing entertainment) had 3 items, factor 3 (professional advancement) consisted of 3 items, factor 4 (to meet new people) generated 3 items, factor 5 (expression information sharing) had 4 items, factor 6 (escapism) resulted in 3 items, factor 7 (social interaction) produced 2 items.

\subsection{Reliability}

Reliability is repeatability or consistency of measurement of the same questions under different conditions, occasions, and on different people (Drost, 2011). In order to get the reliable result of this study, firstly, the survey procedure was standardized by using the same explanation for the study inhibiting student misunderstanding. Secondly, the questions in the questionnaire were long and detailed enough to test their level of attitudes and behaviours. Thirdly, survey questionnaires were delivered them in the similar classes eliminating noise level or any other environmental distractions. Finally, students were drawn from the population randomly and they were heterogeneous enough which also affects reliability factor.

The reliability of the variables was assessed by using Cronbach's alpha. Motivational scale and communication apprehension scale is shown in the Table 4 below.

\section{Table 4. Internal Consistency of Instrument}

\begin{tabular}{lc}
\hline Items & Cronbach Alpha \\
\hline Communication anxiety & .89 \\
Communication easiness & .78 \\
Habitual pass time and companionship & .86 \\
Relaxing entertainment & .89 \\
Professional advancement & .81 \\
To meet new people & .86 \\
Expressive information sharing & .77 \\
Escapism & .80 \\
Social interaction & .72
\end{tabular}

\section{Results}

\subsection{Regression Analysis for Research Question 1}

Regression analysis results revealed a positive significant association between social communication easiness and using SNSs for longer hours $(\beta=0.136, p<0.05)\left(R^{2}=0.019\right)$. Other variables revealed the similar interaction neither with social communication easiness nor with 
social communication anxiety. Results support the fact that participants who were good at faceto-face communication in social life spent long hours in using SNSs. In other words, socially communicative individuals connect to social networking sites and spend their time there for long hours.

\subsection{Regression Analysis for Research Question 2}

\subsubsection{SNS Number and Motives}

Several motives were positively associated with participants' opening social network sites. Individuals who had a need for relaxing entertainment $(\beta=0.228, p<0.05)\left(R^{2}=0.052\right)$, expressive information sharing $(\beta=0.197, p<0.05)\left(R^{2}=0.039\right)$, professional advancement $(\beta=0.127, p<0.05)$ $\left(R^{2}=0.016\right)$, social interaction $(\beta=0.138, p<0.05)\left(R^{2}=0.019\right)$, and to meet new people $(\beta=0.145$, $p<0.05)\left(R^{2}=0.021\right)$ had more number of SNSs. To meet new people was the motivation that only had an effect on the users' tendency to increase the number of SNSs. People who tend to 'meet new people' open different types of SNSs (e.g., Google+, Facebook and so on). Persons who are drawn by 'social interaction' motive tend to keep in touch and communicate with their distanced friends and family members. Individuals who have a need of 'social interaction' tend to increase the number of SNSs and spend more time on using them.

\subsubsection{SNS Frequency and Motives}

Several motives were positively associated with participants' frequency of connecting to SNSs. Individuals who had a need for relaxing entertainment $(\beta=0.263, p<0.05)\left(R^{2}=0.069\right)$, expressive information sharing $(\beta=0.188, p<0.05)\left(R^{2}=0.035\right)$, escapism $(\beta=0.188, p<0.05)\left(R^{2}=0.035\right)$, and habitual pass time $(\beta=0.225, p<0.05)\left(R^{2}=0.051\right)$ frequently connected to $S N S s$.

\subsubsection{SNS Hour and Motives}

Several motives were positively associated with participants' duration of spending their times on SNSs. Individuals who had a need for relaxing entertainment $(\beta=0.317, p<0.05)\left(R^{2}=0.101\right)$, expressive information sharing $(\beta=0.218, p<0.05)\left(R^{2}=0.047\right)$, escapism $(\beta=0.206, p<0.05)$ $\left(R^{2}=0.043\right)$, professional advancement $(\beta=0.208, p<0.05)\left(R^{2}=0.043\right)$, social interaction $(\beta=0.138$, $p<0.05)\left(R^{2}=0.019\right)$, and habitual pass time and companionship $(\beta=0.326, p<0.05)\left(R^{2}=0.106\right)$ spent more time on SNSs. Escapism and habitual pass time \& companionship affected the users' frequency of connection and time spent on SNSs. 
Table 5. Regression Results for the Predictors of SNS by the Number of SNSs, Year of Using SNSs, Frequency of Using SNSs, and Hour of Using SNSs

\begin{tabular}{|c|c|c|c|}
\hline \multicolumn{4}{|c|}{ SNS Number mun SNS Freg. SNS Hour } \\
\hline Social Communication anxiety & 0.031 & 0.023 & 0.075 \\
\hline Social Communication easiness & 0.098 & 0.080 & $0.136^{*}$ \\
\hline Relaxing entertainment & $0.228 * * *$ & $0.263 * * *$ & $0.317 * * *$ \\
\hline Expressive information sharing & $0.197 * *$ & $0.188^{* *}$ & $0.218^{* * *}$ \\
\hline Escapism & 0.089 & $0.188 * *$ & $0.206 * *$ \\
\hline Professional advancement & $0.127 *$ & 0.087 & $0.208 * *$ \\
\hline Social interaction & $0.138^{*}$ & 0.032 & $0.138 *$ \\
\hline Habitual pass time \& compan. & 0.124 & $0.225^{* * *}$ & $0.326 * * *$ \\
\hline To meet new people & $0.145^{*}$ & 0.111 & 0.097 \\
\hline \multicolumn{4}{|l|}{$* p \leq 0.05$} \\
\hline \multicolumn{4}{|l|}{$* * p \leq 0.01$} \\
\hline$* * * p \leq 0.001$ & & & \\
\hline
\end{tabular}

\subsection{Regression Analysis for Research Question 3}

\subsubsection{Facebook Users and Motives}

Facebook using was positively associated with relaxing entertainment $(\beta=0.292, p<0.05)$ $\left(R^{2}=0.085\right)$, and professional advancement $(\beta=0.175, p<0.05)\left(R^{2}=0.031\right)$. Facebook users wanted to get gratifications based on relaxing entertainment and professional advancement by using Facebook.

\subsubsection{Twitter Users and Motives}

Twitter using was positively associated with expressive information sharing $(\beta=0.128, p<0.05)$ $\left(R^{2}=0.016\right)$. Twitter users solicited information sharing gratification by the use of Twitter.

\subsubsection{Facebook-Twitter Users and Motives}

Facebook-Twitter using was positively associated with habitual pass time and companionship $(\beta=0.177, p<0.05)\left(R^{2}=0.031\right)$, and with meeting new people $(\beta=0.149, p<0.05)\left(R^{2}=0.022\right)$. The users who used both Facebook and Twitter used them for the purpose of habitual pass time \& companionship and meeting new people.

\subsubsection{Google+ Users and Motives}

Google+ using was positively associated with habitual pass time and companionship ( $\beta=0.128$, $p<0.05)\left(R^{2}=0.016\right)$, and meeting with new people $(\beta=0.136, p<0.05)\left(R^{2}=0.018\right)$. Google + users 
used Google + to satisfy their gratifications to meet new people as well as habitual pass time \& companionship.

Table 6. Regression Results for the Predictors of the Choice of SNSs

\begin{tabular}{lllcl}
\hline & Facebook & Twitter & Facebook \& Twitter & Google+ \\
\hline Social Communication anxiety & .127 & .112 & .096 & .101 \\
Social Communication easiness & .125 & .055 & .102 & .045 \\
Relaxing entertainment & $.292^{* * *}$ & .018 & .121 & .116 \\
Expressive information sharing & .105 & $.128^{*}$ & .102 & .031 \\
Escapism & .007 & .067 & .061 & .073 \\
Professional advancement & $.175^{* *}$ & .047 & .001 & .123 \\
Social interaction & .104 & .052 & .084 & .013 \\
Habitual pass time \& sompan. & .107 & .053 & $.177^{* *}$ & $.128^{*}$ \\
Tomeet new people & .070 & .072 & $.149 *$ & $.136^{*}$ \\
\hline$* p \leq 0.05$ & & & & \\
$* * p \leq 0.01$ & & &
\end{tabular}

\section{Conclusions, Limitations and Further Suggestions}

Findings support the fact that socially communicative individuals stay connected to SNSs for long hours. In other words, people who are good at social communication are long hours SNS users. The results support the study by Sheldon(2008) and also the rich get richer hypothesis that people who are good at communicating in social settings are also the ones who stay connected to SNSs and thus, active in online relationships. Although, extraversion as the Big Five personality traits is not examined in this study, those individuals' characteristics may be considered similar to extraverts; as they take social communication easy, are good at communication in social settings, and are high in sociability. From this fact, the study confirms the studies in which a high connection is found between extraversion and social media use by Correa, Hinsley, and de Zúñiga (2010), and Gosling, Augustine, Vazire, Holtzman, and Gaddis (2011).

One of the questions that this exploratory research tried to answer was what gratifications users obtained from SNS use, and which type of SNSs (e.g., Facebook, Google+) affected users' usage patterns (e.g., frequency, long hours, the number of SNSs). From the U\&G perspective, there were certain needs (motives) that drove users to use SNSs, increase the number of them, the frequency of connection, and time spent with them. People who had the motivation of "sharing expressive information" and "relaxing entertainment" had more numbers and experience of using SNSs, used them more frequently, and for more hours.

Another important question tried to be answered is whether or not the choice of SNS usage changed according to different motives and which specific motives drove users to use certain type of SNSs on cyber space. In varying degrees, certain gratifications had a significant impact on the 
users' usage patterns of different network sites and perceived importance of Facebook, Twitter, Facebook-Twitter, and Google+ in their lives. People who have different motives have different choices of SNSs. The needs of Twitter users were different than Facebook users: Twitter users used Twitter for expressive information sharing which is the main existence of Twitter. In their studies Holton, Baek, Coddington, and Yaschur (2013) found that interpersonal utility and passing time were the main motives for using Twitter; and for Facebook; there was a need to belong and a need for self-presentation in Nadkarni and Hofmann's (2012) study; and finally, they were social surveillance, recognition, entertainment, and network maintenance needs in Zhang, Tang, and Leung's (2011) study. In this study, however, the main motives of Facebook use were relaxing entertainment and professional advancement. Hunt, Atkin, and Krishnan (2012) and Hess (2012) expressed that relaxing entertainment is one of the strongest motives and the main reasons for the existence of Facebook. By connecting to Facebook, users can find advertisements personally designed for them to fit their demographic and psychographic backgrounds. While designing and placing those advertisements for Facebook, instead of static, every day, and boring commercials which take place and can be seen on users' Facebook Web pages, users' needs for relaxing entertainment should be primarily considered. The commercials offering Facebook users more fun and entertainment will not be only of interest to the users but also create online word of mouth. Furthermore, commercials offering professional advancement opportunities (such as English courses, and other certificate programs) shouldn't be forgotten, as it is the second most important motivation why youngsters connect to Facebook.

Google+ users' and Facebook-Twitter users' main motives to use their social networking sites were for meeting with new people and for habitual pass time \& companionship. Google+ which combines many features including Twitter, Skype, and Facebook may tend to get a bigger share in the pie of cyber space in the near future. In addition, Facebook-Twitter users may have used their networking sites for many years and therefore developed a habit of using them as well as finding their friends and peers there which might be the main reasons why the users gratify their needs of habitual pass time \& companionship by using them. Google+ opened its doors to users by offering many features such as meeting and interacting with people, customers, or employees, and is suitable for group discussions and long conversations which are the essential elements for relationship building. Thus it is a unique social networking platform and neither Facebook nor Twitter itself has those features (Clark, 2013). As a result of motivational competition, in the near future some advertising dollars will be shifted from Facebook and Twitter to Google+, unless they combine different features, functions, and more flexibility to their users.

This study is limited with the investigation of numbers of using SNSs, frequency of using SNSs, and hours of using SNSs. For further studies, the number of friends (the number of social contacts) may be well worth investigating as a predictor of social interaction. Since, some users of SNSs have up to 50 to 60 friends (contacts), while others are approaching 500 to 600 . Answering the question of "what kind of characteristic makes them to own more online friends than others?" is important to understand the differences among SNS users.

\section{References}

Akdenizli, B. (2015). Introduction. In B. Akdenizli (Ed.). Digital transformations in Turkey: Current perspectives in communication studies. (pp. ix-xv). London: Lexington Books.

Alloway, T. P. and Alloway, R. G. (2012). The impact of engagement with social networking sites (SNSs) on cognitive skills. Computers in Human Behavior, 28, 1748-1754. 
Armstrong, C. B. and Rubin, A. M. (1989). Talk radio as interpersonal communication.Journal of Communication,39 (2), 84-94.

Baek, K., Holton, A., Harp, D. and Yaschur, C. (2011). The links that bind: Uncovering novel motivations for linking on Facebook. Computers in Human Behavior, 27, 2243-2248.

Berger, B. A., Richmond, V., McCroskey, J. C. and Baldwin, H. J. (1984). Reducing communication apprehension: Is there a better way?.American Journal of Pharmaceutical Education, 48: 46-50.

Berry, S. (2007). Situational Communication Apprehension Measure. In R. Reynolds, R. Woods, \& J. Baker (Eds.) Handbook of Research on Electronic Surveys and Measurements(pp. 376-378). Hershey, PA: . doi:10.4018/978-1-59140-792-8.ch056

Boyd, d. m. and Ellison, N. B. (2007). Social network sites: Definition, history, and scholarship. Journal of Computer-Mediated Communication, 13(1), article 11. http://jcmc.indiana.edu/vol13/issue1/boyd.ellison. html19.11.2012

Burke, M., Marlow, C. and Lento, T. (2010). Social network activity and social well-being. The proceedings of the SIGCHI Conference on Human Factors in Computing Systems, ACM: New York. 1909-1912. doi>10.1145/1753326.1753613

Campbell, J. (2006). Media Richness, Communication Apprehension and Participation in Group Videoconferencing. Journal of Information, Information Technology, and Organizations, 1, 87-96.

Clark, D. (2013). Why You Should Be On Google Plus (Even Though No One Else Is). http://www.forbes.com/ sites/dorieclark/2013/01/04/why-you-should-be-on-google-plus-even-though-no-one-else-is/ 10.4.2014

Correa, T., Hinsley, A. W. and de Zúñiga, H. G. (2010). Who interacts on the Web?: The intersection of users' personality and social media use. Computers in Human Behavior, 26, 247-253.

Drost, E. A. (2011). Validity and reliability in social science research. Education Research and Perspectives 38 (1), 105-123.

Duggan, M.,Ellison, N. B., Lampe, C., Lenhart, A. and Madden, M. (2015). Social media update 2014. http:// www.pewinternet.org/2015/01/09/social-media-update-2014/21.4.2015

Erdoğan, Y. (2008). Exploring the relationships among Internet usage, Internet attitudes and loneliness of Turkish adolescents. Cyberpsychology: Journal of Psychosocial Research on Cyberspace,2(2). http://www. cyberpsychology.eu/view.php?cisloclanku=2008111802\&article $=118.11 .2012$

Gosling, S. D., Augustine, A. A., Vazire, S., Holtzman, N. and Gaddis, S. (2011). Manifestations of personality in online social networks: Self-reported Facebook-related behaviors and observable profile information. CyberPsychology, 14 (9), 483-488.

"Gratification" (n.d.). http://oxforddictionaries.com/definition/english/gratification?q=gratification8.1.2013

Hess, S. (2012). New Facebook study reveals motivation behind Facebook visits. http://www.webpronews.com/ new-facebook-study-reveals-motivation-behind-facebook-visits-2012-06 10.4.2014

Ho, S. S. and McLeod, D. M. (2008). Social-psychological influences on opinion expression in faceto-face and computer-mediated communication. Communication Research, 35 (2), 190-207. DOI: $10.1177 / 0093650207313159$

Holton, A. E., Baek, K. H., Coddington, M. and Yaschur, C. (2013). Soliciting reciprocity socializing, communality, and other motivations for linking on Twitter. The proceedings of the 2013 International Symposium on Online Journalism, Austin, Texas: University of Texas atAustin. http://www.academia.edu/3624260/Soliciting 
Reciprocity_Socializing_communality_and_other_motivations_for_linking_on_Twitter10.4.2014

Hughes, D. J., Rowe, M., Batey, M. and Lee, A. (2012). A tale of two sites: Twitter vs. Facebook and the personality predictors of social media usage. Computers in Human Behavior, 28, 561-569.

Hunt, D., Atkin, D. and Krishnan, A. (2012). The influence of computer-mediated communication apprehension on motives for Facebook use. Journal of Broadcasting \&Electronic Media, 56 (2), 187-202. DOI: $10.1080 / 08838151.2012 .678717$

"Internet stats and Facebook usage in Europe 2014 mid-year statistics" (2014).http://www.internetworldstats. com/stats4.htm\#europe 1.5.2015

"Internet top 10 countries in Europe" (2014). http://www.internetworldstats.com/stats4.htm\#europe 1.5.2015

Kaplan, A. M. and Haenlein, M. (2010). Users of the world, unite! The challenges and opportunities of social media. Business Horizons, 53, 59-68.

Katz, E., Blumer, J. G. and Gurevitch, M. (1973). Uses and gratifications research. Public Opinion Quarterly, 37 (4), 509-523.

Kaye, B. K. and Johnson, T. J. (2002). Online and in the know: Uses and gratifications of the web for political information. Journal of Broadcasting \& Electronic Media, 46 (1), 54-71.

Kaye, B. K. and Johnson, T. J. (2004). A Web for all reasons: Uses and gratifications of Internet components for political information. Telematics and Informatics, 21, 197-223.

Kim, Y., Sohn, D. and Choi, S. M. (2011). Cultural difference in motivations for using social network sites: A comparative study of American and Korean college students. Computers in Human Behavior, 27, 365-372.

"Leading social networks worldwide as of March 2015, ranked by number of active users (in millions)" (n.d.). http://www.statista.com/statistics/272014/global-social-networks-ranked-by-number-of-users/ 1.5.2015

Lee, C. S. and Ma, L. (2012). News sharing in social media: The effect of gratifications and prior experience. Computers in Human Behavior 28, 331-339.

"Longitudinal study, wave 2: Facebook users read more and post less; motivations for twitter usage change" (2014). http://www.redeftie.eu/?p=20610.4.2014

Maxwell, E. M. (2012). Motivations to tweet: A uses and gratifications perspective of twitter use during natural disaster. Unpublished Master thesis. Tuscaloosa, Alabama: The University of Alabama.

McCord, B., Rodebaugh, T.L., \& Levinson, C.A. (2014). Facebook: Social uses and anxiety. Computers in Human Behavior, 34, 23-27.

McCroskey, J.C. (1984). The communication apprehension perspective. In J.A. Daly and J. C. McCroskey (Eds.), Avoiding communication: Sheyness, reticence, and communication, (pp. 13-38). Beverly Hills, CA: SAGE Publications.

McCroskey, J. C., Booth-Butterfield, S. and Payne, S. K. (1989). The Impact of communication apprehension on college student retention and success. Communication Quarterly, 37 (2), 100-107.

McCroskey, J. C. and Sheahan, M. E. (1978). Communication apprehension, social preference, and social behavior in a college environment. Communication Quarterly, 26 (2), 41-45.

Miller, C. C. (2014). The Loyal Users of Google Plus Say It Is No Ghost Town. http://bits.blogs.nytimes. com/2014/02/19/the-loyal-users-of-google plus-say-it-is-no-ghost-town/ 10.4.2014 
Miyata, K. and Kobayashi, T. (2008). Causal relationship between Internet use and social capital in Japan. Asian Journal of Social Psychology, 11, 42-52. DOI: 10.1111/j.1467-839X.2007.00242.x

Mustafa, N., Ibrahim, F., Mahmud, W. A. W., Ahmad, F., Kee, C. P. and Mahbob, M. H. (2011). Diffusion of innovations: The adoption of Facebook among youth in Malaysia. The Innovation Journal: The Public Sector Innovation Journal, 16(3), article 8, 1-15.

Nadkarni, A. and Hofmann, S. G. (2012). Why Do People Use Facebook? Personality and Individual Differences, 52 (3), 243-249. doi:10.1016/j.paid.2011.11.007

Papacharissi, Z. and Rubin, A. M. (2000). Predictors of Internet use. Journal of Broadcasting \& Electronic Media, 44 (2), 175-196.

Perse, E. M. and Courtright, J. A. (1993). Normative images of communication media: Mass and interpersonal channels in the new media environment. Human Communication Research, 19 (4), 485-503.

Pitt, L. F. and Ramaseshan, B. (1990). Apprehension about communication and salespersons' performace. Psychological Reports, 67, 1355-1362.

Raacke, J. and Bonds-Raacke, J. (2008). MySpace and Facebook: Applying the uses and gratifications theory to exploring friend-networking sites. CyberPsychology \& Behavior, 11 (2), 169-174.

Rohani, V. A. and Hock, O. S. (2010). On social network Web sites: Definition, features, architectures and analysis tools. Journal of Advances in Computer Research, 2, 41-53.

Ross, C., Orr, E. S., Sisic, M., Arseneault, J. M., Simmering, M. G. and Orr, R. R. (2009). Personality and motivations associated with Facebook use. Computers in Human Behavior, 25, 578-586.

Scott, C. R. and Rockwell, S. C. (1997). The effect of communication, writing, and technology apprehension on likelihood to use new communication technologies. Communication Education, 46, 44-62.

Sheldon, P. (2008). The relationship between unwillingness-to-communicate and students'Facebook use. Journal of Media Psychology, 20 (2), 67.75.

Smock, A. D., Ellison, N. B., Lampe, C. and Wohn, D. Y. (2011). Facebook as a toolkit: A uses and gratification approach to unbundling feature use. Computers in Human Behavior, 27, 2322-2329.

"Social" (n.d.). http://www.macmillanddictionary.com/dictionary/british/social8.1.2013

"Social media" (n.d.). http://oxforddictionaires.com/definition/english/social\%2Bmedia8.1.2013

Stefanone, M. A., Hurley, C. M. and Yang, Z. J. (2013). Antecedents of online information seeking. Information, Communication \& Society, 16 (1), 61-81, DOI: 10.1080/1369118X.2012.656137

"Top 10 countries with most Facebook users 2014" (2014). http://addictivelists.com/top-10-countries-with-mostfacebook-users-2014/1.5.2015

Tufekci, Z. (2010). Who acquires friends through social media and why? "Rich get richer" versus "seek and ye shall find". Proceedings of the Fourth International AAAI Conference on Weblogs and Social Media, 170-177.

Wang, Q., Fink, E. L., and Cai, D. A. (2008). Loneliness, gender, and parasocial interaction: A uses and gratifications approach. Communication Quarterly, 56 (1), 87-109.

Wang, Z., Tchernev, J. M. and Solloway, T. (2012). A dynamic longitudinal examination of social media use, 
needs, and gratifications among college students. Computers in Human Behavior, 28, 1829-1839.

Watson, B. R. (2007). Speaking up in the $21^{\text {st }}$ century: The effects of communication apprehension and Internet self-efficacy on use of social networking websites. Unpublished master thesis, Columbia: University of Missouri. Woods, R. (2007). Personal Report of Communication Apprhension. In R. Reynolds, R. Woods and J. Baker (Eds.) Handbook of Research on Electronic Surveys and Measurements (pp. 320-322). Hershey, PA: IGI Global. doi:10.4018/978-1-59140-792-8.ch042

Wrench, J. S., Brogan, S. M., McCroskey, J. C. and Jowi, D. (2008). Social communication apprehension: The intersection of communication apprehension and social phobia. Human Communication: A Publication of the Pacific and Asian Communication Association, 11 (4), 409-430.

Wrench, J. S. and Punyanunt-Carter, N. M. (2007). The relationship between computer-mediated communication competence, apprehension, self-efficacy, perceived confidence, and social presence. Southern Communication Journal, 72 (4), 355-378.

Zhang, Y., Tang, L. S-T. and Leung, L. (2011). Gratifications, collective self-esteem, online emotional openness, and trait-like communication apprehension as predictors of Facebook uses. Cyberpsychology, Behavior, and Social Networking, 14 (12), 733-739. DOI: 10.1089/cyber.2010.0042

Zhou, Z. and Bao, Y. (2002). Users' attitudes toward Web advertising: Effects of Internet motivation and Internet ability. Advances in Consumer Research. 29, 71-78.

Zywica, J. and Danowski, J. (2008). The faces of Facebookers: Investigating social enhancement and social compensation hypotheses; predicting FacebookTM and offline popularity from sociability and self-esteem, and mapping the meanings of popularity with semantic networks. Journal of Computer-Mediated Communication, $14,1-34$.

\section{Acknowledgement}

I thank to Prof. Dr. Richard Pettyand the members of the Department of Psychology at Ohio State University for giving me an opportunity to present this study in their colloquiumand their invaluable comments and contributions. I also appreciate the recommendations given to me by the editor and reviewers of Akdeniz Illetişim Dergisi.

\section{APPENDICES}

\section{APPENDIX-A}

The name of UFND courses are listed below and their Turkish names are in italic:

UFND010 Human Sciences - İnsan Bilimleri

UFND020 Research Culture - Araştırma Kültürü

UFND030 Design Culture - Tasarım Kültürü

UFND040 Esthetics Culture - Estetik Kültürü

UFND050 Ethics Culture - Etik Kültürü

UFND060 Project Culture - Proje Kültürü

\section{APPENDIX-B}

Social Communication Apprehension Scale by Wrench, Brogan, McCroskey, and Jowi (2008)

1. I always feel anxious in social situations.

2. I experience anxiety when I communicate with people in social settings.

3. Even small get-togethers make me apprehensive.

4. At a party, I tend to hangout near a wall away from people.

5. Social interaction makes me anxious.

6. I get really nervous when I have to interact with people at a party.

7. I tend to be very apprehensive while communicating in social situations.

8. I am usually anxious when talking to people in a bar.

9. I get nervous when I talk to people in a nightclub.

10. I am outgoing when surrounded by a lot of people.

11. I am usually very outgoing at a dinner party. 
12. I have no problems talking to people in a nightclub.

13. I am at ease at parties.

14. Social interaction is the best part of my day.

15. I am less shy than most people in social situations.

16. I seldom feel anxious in social situations.

17. I am usually at ease when talking to people in a bar.

18. I can communicate with people in social settings without experiencing anxiety.

Social Communication Apprehension Scale Used in this Study

1. I always feel anxious in social situations.

2. I experience anxiety when I communicate with people in social settings.

3. Even small get-togethers make me apprehensive.

4. At a party, I tend to hangout near a wall away from people.

5. Social interaction makes me anxious.

6. I get really nervous when I have to interact with people at a party.

7. I tend to be very apprehensive while communicating in social situations.

8. I am usually anxious when talking to people in open public spaces.

\section{OMITED}

10. I am outgoing when surrounded by a lot of people.

11. I am usually very outgoing at a dinner party.

12. I am at ease at parties.

13. OMITED

14. Social interaction is the best part of my day.

15. I am less shy than most people in social situations.

16. I seldom feel anxious in social situations.

17. I am usually at ease when talking to people in open public spaces.

18. I can communicate with people in social settings without experiencing anxiety.

Not: Differences are underlined.

\section{APPENDIX-C}

Smock, Ellison, Lampe, and Wohn (2011), used only 1 item to evaluate 'to meet new people' in their measures; in this study, in addition to meeting new people, the following two items were included:

Chatting with new people

Meeting new people

Exchanging ideas with new people 